\title{
Technical Note: Determination of formaldehyde mixing ratios in air with PTR-MS: laboratory experiments and field measurements
}

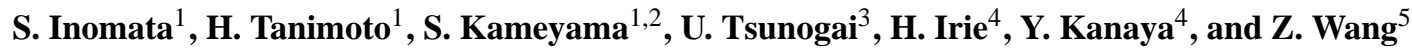 \\ ${ }^{1}$ National Institute for Environmental Studies, 16-2 Onogawa, Tsukuba, Ibaraki 305-8506, Japan \\ ${ }^{2}$ JSPS Research Fellow, Japan \\ ${ }^{3}$ Hokkaido University, Kita 10 Nishi 8, Kita-ku, Sapporo, Hokkaido 060-0810, Japan \\ ${ }^{4}$ Frontier Research Center for Global Change, Japan Agency for Marine-Earth Science and Technology, 3173-25 \\ Showa-machi, Yokohama, Kanagawa 236-0001, Japan \\ ${ }^{5}$ LAPC/NZC, Institute of Atmospheric Physics, Chinese Academy of Sciences, Beijing 10029, China
}

Received: 20 August 2007 - Published in Atmos. Chem. Phys. Discuss.: 3 September 2007

Revised: 23 November 2007 - Accepted: 23 November 2007 - Published: 23 January 2008

\begin{abstract}
Formaldehyde (HCHO), the most abundant carbonyl compound in the atmosphere, is generated as an intermediate product in the oxidation of nonmethane hydrocarbons. Proton transfer reaction mass spectrometry (PTR-MS) has the capability to detect $\mathrm{HCHO}$ from ion signals at $m / z 31$ with high time-resolution. However, the detection sensitivity is low compared to other detectable species, and is considerably affected by humidity, due to back reactions between protonated $\mathrm{HCHO}$ and water vapor prior to analysis. We performed a laboratory calibration of PTR-MS for HCHO and examined the detection sensitivity and humidity dependence at various field strengths. Subsequently, we deployed the PTR-MS instrument in a field campaign at Mount Tai in China in June 2006 to measure HCHO in various meteorological and photochemical conditions; we also conducted intercomparison measurements by Multi-Axis Differential Optical Absorption Spectroscopy (MAX-DOAS). Correction of interference in the $m / z 31$ signals by fragments from proton transfer reactions with methyl hydroperoxide, methanol, and ethanol greatly improves agreement between the two methods, giving the correlation $[\mathrm{HCHO}]_{\mathrm{MAX}-\mathrm{DOAS}}=(0.99 \pm 0.16)$ $[\mathrm{HCHO}]_{\mathrm{PTR}-\mathrm{MS}}+(0.02 \pm 0.38)$, where error limits represent $95 \%$ confidence levels.
\end{abstract}

\section{Introduction}

Proton transfer reaction mass spectrometry (PTR-MS) is a technique that allows on-line measurements of volatile organic compounds (VOCs) at trace levels in air (Lindinger et al., 1998a, 1998b; de Gouw and Warneke, 2007). Proton

Correspondence to: S. Inomata

(ino@nies.go.jp) transfer is an example of chemical ionization; it enables soft ionization of chemical species that have a proton affinity (PA) higher than that of the reagent species (i.e. water):

$\mathrm{H}_{3} \mathrm{O}^{+}+\mathrm{VOC} \rightarrow \mathrm{VOC} \cdot \mathrm{H}^{+}+\mathrm{H}_{2} \mathrm{O}$

PTR-MS allows monitoring of numerous VOCs of atmospheric interest with a high sensitivity (10-100 parts per trillion by volume (pptv)) and rapid response time (0.1-10 s). PTR-MS is potentially advantageous compared to gas chromatographic (GC) analyses because it does not require any sample treatment such as drying and/or preconcentration, and it is suitable for oxygenated VOCs, which are difficult to quantify from canister samples. PTR-MS is now used in many branches of atmospheric chemistry research, including air quality monitoring (e.g. Karl et al., 2001a, 2003a, 2003b; de Gouw et al., 2003), flux measurements (e.g. Holzinger et al., 1999; Karl et al., 2001b; Grabmer et al., 2004; Spirig et al., 2005), and oxidation studies (e.g. D'Anna et al., 2005; Paulsen et al., 2005; Lee et al., 2006a, 2006b).

Formaldehyde (HCHO) is an intermediate product in the oxidation pathways of nonmethane hydrocarbons emitted by anthropogenic and biogenic activities. In addition, formaldehyde is thought to be a probable carcinogen (Seinfeld and Pandis, 1998); this has heightened interest in atmospheric formaldehyde measurements, especially in urban areas. Reactions with hydroxyl radicals $(\mathrm{OH})$ and photolysis are the main HCHO loss processes (Atkinson, 2000; Calvert et al., 2000):

$$
\begin{aligned}
& \mathrm{HCHO}+\mathrm{OH} \rightarrow \mathrm{HCO}+\mathrm{H}_{2} \mathrm{O} \\
& \mathrm{HCHO}+\mathrm{h} v \rightarrow \mathrm{H}_{2}+\mathrm{CO}(\lambda<365 \mathrm{~nm}) \\
& \mathrm{HCHO}+\mathrm{h} v \rightarrow \mathrm{H}+\mathrm{HCO}(\lambda<329 \mathrm{~nm})
\end{aligned}
$$

Published by Copernicus Publications on behalf of the European Geosciences Union. 


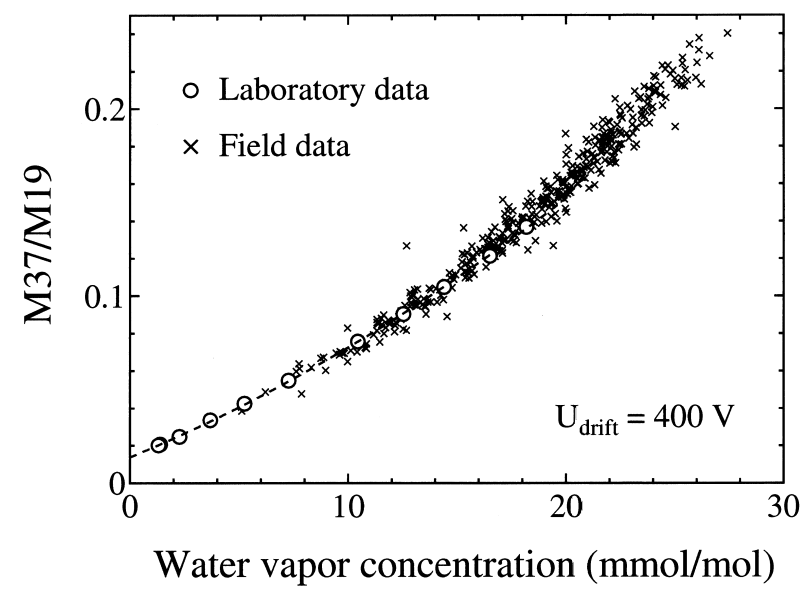

Fig. 1. Relative intensity of $\mathrm{H}_{3} \mathrm{O}^{+} \cdot \mathrm{H}_{2} \mathrm{O}$ to $\mathrm{H}_{3} \mathrm{O}^{+}$(M37/M19) as a function of water vapor concentration $(\mathrm{mmol} / \mathrm{mol})$ in sample air. A dashed line shows the best-fit curve for data obtained in the laboratory.

The $\mathrm{HCO}$ and $\mathrm{H}$ produced generate the hydroperoxy radical $\left(\mathrm{HO}_{2}\right)$ as follows:

$$
\begin{aligned}
& \mathrm{HCO}+\mathrm{O}_{2} \rightarrow \mathrm{HO}_{2}+\mathrm{CO} \\
& \mathrm{H}+\mathrm{O}_{2}+\mathrm{M} \rightarrow \mathrm{HO}_{2}+\mathrm{M}
\end{aligned}
$$

The photolysis channel (R3b) followed by reactions (R4) and (R5) is a net source of odd hydrogen radicals, $\mathrm{HO}_{\mathrm{x}}$ $\left(\mathrm{HO}_{\mathrm{x}}=\mathrm{HO}_{2}+\mathrm{OH}+\mathrm{H}\right)$. These species contribute to the formation of tropospheric ozone $\left(\mathrm{O}_{3}\right)$, a key chemical species in controlling the oxidizing capacity of the atmosphere.

Several techniques based on spectroscopic, chromatographic, and fluorometric methods are used for ambient measurements of HCHO. Differential Optical Absorption Spectroscopy (DOAS) (e.g. Lawson et al., 1990; Cárdenas et al., 2000; Grossmann et al., 2003; Hak et al., 2005), FourierTransform Infrared interferometry (e.g. Lawson et al., 1990; Cárdenas et al., 2000; Hak et al., 2005), and Tunable Diode Laser Absorption Spectroscopy (e.g. Harris et al., 1989; Fried et al., 1997, 2003; Zavala et al., 2006) are spectroscopic methods often used for in situ measurements, where the absorption by $\mathrm{HCHO}$ in the UV or IR regions is detected with a long-path setup such as a White cell system. The Multi-Axis Differential Optical Absorption Spectroscopy (MAX-DOAS) is a relatively new technique, where scattered solar radiation is collected by telescope from different directions in order to derive the column densities of absorbing species. The vertical profile of $\mathrm{HCHO}$ in the troposphere can be measured by MAX-DOAS in combination with a radiative transfer model (Heckel et al., 2005). In chromatographic methods, HCHO is collected as a 2,4dinitrophenylhydrazine (DNPH) derivative, and then analyzed by high performance liquid chromatography (HPLC) (e.g. Tanner and Meng, 1984; Grosjean, 1991; Lee and Zhou,
1993; Gilpin et al., 1997). Other techniques include wet chemical fluorometric detection using the Hantzsch reaction, which requires the transfer of $\mathrm{HCHO}$ from the gas phase into the liquid phase and employs the fluorescence of 3,5diacetyl-1,4-dihydrolutidine at $510 \mathrm{~nm}$, produced from the reaction of aqueous $\mathrm{HCHO}$ with a solution containing 2,4pentadione and $\mathrm{NH}_{3}$ (e.g. Steinbacher et al., 2004; Hak et al., 2005). Extensive intercomparison has been performed among these different techniques for ambient $\mathrm{HCHO}$ measurements, but the degree of agreement has varied from good to very poor, with no discernible patterns identified (e.g. Lawson et al., 1990; Gilpin et al., 1997; Cárdenas et al., 2000; Grossmann et al., 2003; Hak et al., 2005).

Various authors have detected HCHO with PTR-MS by monitoring ion signals of protonated $\mathrm{HCHO}\left(\mathrm{HCHO} \cdot \mathrm{H}^{+}\right)$at $m / z 31$ (Hansel et al., 1997; Holzinger et al., 1999; Karl et al., 2003b; Steinbacher et al., 2004; D’Anna et al., 2005; Lee et al., 2006a, 2006b); the protonated HCHO is created as follows:

$\mathrm{H}_{3} \mathrm{O}^{+}+\mathrm{HCHO} \rightarrow \mathrm{HCHO} \cdot \mathrm{H}^{+}+\mathrm{H}_{2} \mathrm{O}$

One of the potential advantages of measuring $\mathrm{HCHO}$ by PTR-MS in the field is the ability to simultaneously observe precursor molecules of $\mathrm{HCHO}$, such as isoprene. However, $\mathrm{HCHO}$ has a PA only slightly higher than that of water, and so the exothermicity of reaction (R6) is small. Consequently, the reverse reaction of reaction (R6):

$\mathrm{HCHO} \cdot \mathrm{H}^{+}+\mathrm{H}_{2} \mathrm{O} \rightarrow \mathrm{H}_{3} \mathrm{O}^{+}+\mathrm{HCHO}$

is not negligible (Hansel et al., 1997). The rate constant for the reverse reaction is several orders of magnitude lower than that of the forward reaction, but since the concentration of $\mathrm{H}_{2} \mathrm{O}$ in the reactor is much higher than the concentration of $\mathrm{HCHO}$, the overall rates of the forward and reverse reactions can be comparable. As a result, the protonation of $\mathrm{HCHO}$ is less efficient, and is expected to depend on the humidity of the sample air. There have been no experimental reports on the humidity dependence of HCHO detection by PTR-MS (de Gouw and Warneke, 2007). In addition, according to results from field measurements detecting ion signals at $m / z 31$ by PTR-MS, the correlation between independent measurements of HCHO by the PTR-MS and Hantzsch methods was poor (Steinbacher et al., 2004), suggesting that fragments of other compounds are present in the background, and interfere with the signal at $m / z 31$.

In the present work, we present detailed procedures for the calibration of PTR-MS for HCHO measurements, including determination of the detection sensitivity and its humidity dependence. We present an intercomparison of PTR-MS and MAX-DOAS techniques for ambient HCHO measurements made during an intensive field campaign at Mount Tai in China in June 2006. We discuss possible causes for background signals at $m / z, 31$ in $\mathrm{HCHO}$ measurements performed by PTR-MS, and suggest a correction method for improving the agreement between PTR-MS and MAX-DOAS results. 

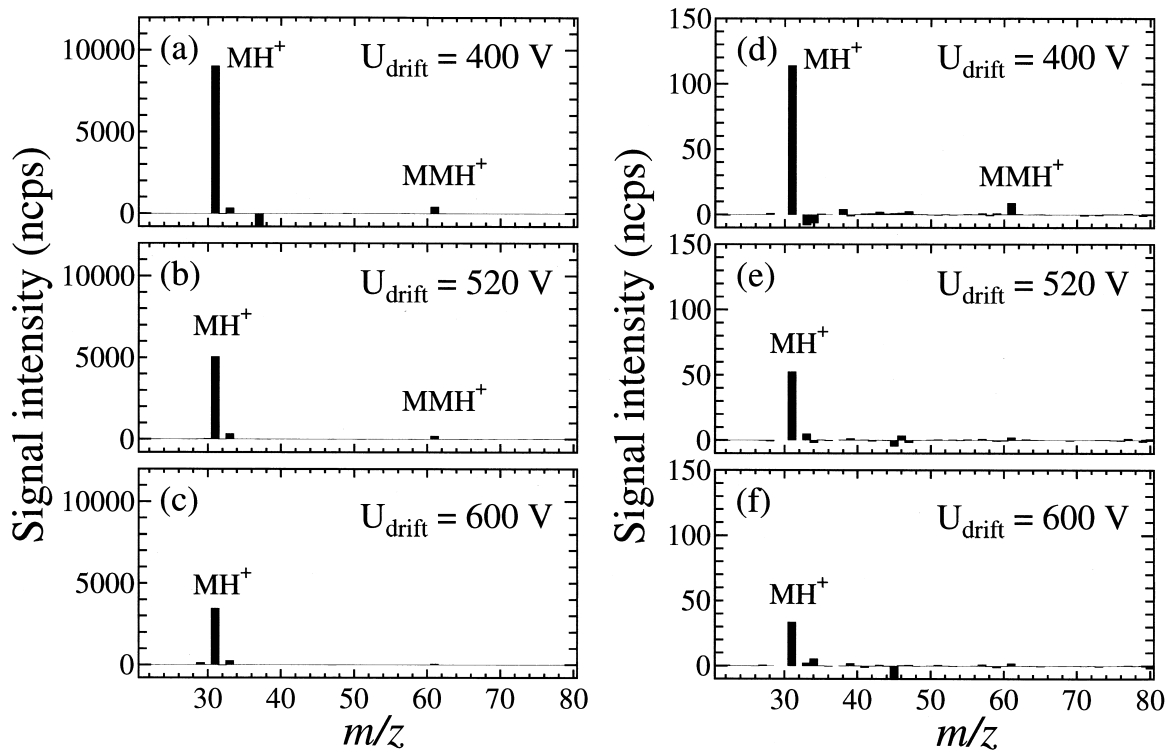

Fig. 2. Mass spectrum of $\mathrm{HCHO}$ at three different drift tube $E / N$ ratios in dry conditions, obtained by the direct introduction method (a-c) and dynamic dilution method $(\mathbf{d}-\mathbf{f}) .(\mathrm{a}-\mathrm{c})$ : $[\mathrm{HCHO}]=1.02 \mathrm{ppmv} ;(\mathrm{d}-\mathrm{f})$ : $[\mathrm{HCHO}]=23.3 \mathrm{ppbv}$. Signals were normalized to a $\mathrm{H}_{3} \mathrm{O}^{+}$intensity of $10^{6} \mathrm{cps}$, and background mass spectra without $\mathrm{HCHO}$ (obtained from $\mathrm{N}_{2}(\mathrm{a}-\mathrm{c})$ or zero air (d-f) only) were subtracted.

\section{Experimental}

\section{$2.1 \quad$ PTR-MS instrument}

The instrument used in the present work was a commercially available PTR-MS instrument (IONICON Analytik GmbH, Innsbruck, Austria). PTR-MS instruments have been described in detail elsewhere (e.g. Lindinger et al., 1998a, 1998b; de Gouw and Warneke, 2007). Briefly, the instrument consists of (1) a discharge ion source to produce the $\mathrm{H}_{3} \mathrm{O}^{+}$ ions; (2) a drift tube, in which the proton transfer reactions between $\mathrm{H}_{3} \mathrm{O}^{+}$and VOCs take place; and (3) a quadrupole mass spectrometer for the detection of reagent and product ions.

In a hollow cathode discharge ion source, $\mathrm{H}_{3} \mathrm{O}^{+}$ions were produced from a pure water vapor flow of $7.8 \mathrm{sccm}$. The air sample was introduced into the drift tube at a flow rate of $22 \mathrm{sccm}$; the drift tube pressure was held at 2.1 mbar. Most of the water vapor in the ion source was removed by a pump, but a small fraction of the water escaped into the drift tube, leading to an extra moistening of the sample air in the drift tube. The sampling inlet and drift tube were held at $105^{\circ} \mathrm{C}$.

The drift tube consisted of stainless steel ring electrodes, separated by Teflon rings for electrical isolation. The ring electrodes were connected to a resistor network, which divided the overall drift voltage $\left(U_{\text {drift }}\right)$ into a homogeneously increasing voltage and established a homogeneous electric field inside the drift tube. The electric field was applied along the drift tube in order to avoid substantial formation of cluster ions, $\mathrm{H}_{3} \mathrm{O}^{+}\left(\mathrm{H}_{2} \mathrm{O}\right)_{n}, n=1,2, \ldots$ :

$\mathrm{H}_{3} \mathrm{O}^{+}+\mathrm{H}_{2} \mathrm{O} \leftrightarrow \mathrm{H}_{3} \mathrm{O}^{+} \cdot \mathrm{H}_{2} \mathrm{O}$

$$
\mathrm{H}_{3} \mathrm{O}^{+} \cdot\left(\mathrm{H}_{2} \mathrm{O}\right)_{n}+\mathrm{H}_{2} \mathrm{O} \leftrightarrow \mathrm{H}_{3} \mathrm{O}^{+} \cdot\left(\mathrm{H}_{2} \mathrm{O}\right)_{n+1}
$$

In the drift tube, trace gases such as VOCs in the sample air were available to be ionized by proton transfer reactions as shown earlier in reaction (R1). A fraction of the reagent ions $\left(\mathrm{H}_{3} \mathrm{O}^{+}, \mathrm{H}_{3} \mathrm{O}^{+} \cdot\left(\mathrm{H}_{2} \mathrm{O}\right)_{n}\right)$ and the product ions $\left(\mathrm{VOC} \cdot \mathrm{H}^{+}\right)$was extracted through a small orifice into the quadrupole mass spectrometer. The ions were detected by a secondary electron multiplier (SEM) for ion pulse counting.

The count rate of the reagent ion, $i\left(\mathrm{H}_{3} \mathrm{O}^{+}\right)$, calculated from the count rate at $m / z 21$ multiplied by 500, was typically $1 \times 10^{7} \mathrm{cps}$. Although the reactant VOCs are present in the low parts per million by volume (ppmv) range, the proton transfer reactions do not decrease $\left[\mathrm{H}_{3} \mathrm{O}^{+}\right]$significantly; i.e. $\left[\mathrm{H}_{3} \mathrm{O}^{+}\right]>>\left[\mathrm{VOC} \cdot \mathrm{H}^{+}\right]$. Under these conditions, and if the reverse reaction of reaction ( $\mathrm{R} 1)$ is negligible, the count rate of the $\mathrm{VOC} \cdot \mathrm{H}^{+}$ions, $i\left(\mathrm{VOC} \cdot \mathrm{H}^{+}\right)$, can be calculated from

$$
\begin{aligned}
i\left(\mathrm{VOCH}^{+}\right) & =i\left(\mathrm{H}_{3} \mathrm{O}^{+}\right)\left(1-e^{-k[\mathrm{VOC}] t}\right) \\
& \approx i\left(\mathrm{H}_{3} \mathrm{O}^{+}\right) k[\mathrm{VOC}] t
\end{aligned}
$$

where $t$ is the reaction time (the residence time of the reagent ions in the drift tube, typically $100 \mu \mathrm{s}$ ) and $k$ is the proton transfer reaction rate constant (typically $2 \times 10^{-9} \mathrm{~cm}^{3}$ molecule ${ }^{-1} \mathrm{~s}^{-1}$ ).

\subsection{Laboratory calibration}

Calibrations of $\mathrm{HCHO}$ were performed at three field strengths, $E / N$, of the drift tube: 108,140 , and $162 \mathrm{Td}$ $\left(\mathrm{Td}=10^{-17} \mathrm{~cm}^{2} \mathrm{~V}\right.$ molecule $\left.{ }^{-1}\right)$, where $E$ is the electric field 
Table 1. Parameters of the PTR-MS instrument and HCHO calibrations.

\begin{tabular}{|c|c|c|c|}
\hline \multicolumn{4}{|c|}{ PTR-MS setup } \\
\hline$U_{\text {drift }}(\mathrm{V})$ & 400 & 520 & 600 \\
\hline$T_{\text {drift }}\left({ }^{\circ} \mathrm{C}\right)$ & 105 & 105 & 105 \\
\hline$P_{\text {drift }}$ (mbar) & 2.1 & 2.1 & 2.1 \\
\hline$L_{\text {drift }}(\mathrm{cm})$ & 9.2 & 9.2 & 9.2 \\
\hline$t(\mu \mathrm{s})$ & 114 & 87 & 76 \\
\hline$E / N(\mathrm{Td})$ & 108 & 140 & 162 \\
\hline $\mathrm{KE}_{\mathrm{cm}}(\mathrm{eV})$ & 0.10 & 0.17 & 0.23 \\
\hline \multicolumn{4}{|c|}{ Detection sensitivity of HCHO (ncps/ppbv) } \\
\hline Direct introduction $(=m)^{a}$ & $8.9 \pm 0.3$ & $4.9 \pm 0.2$ & $3.4 \pm 0.2$ \\
\hline Dynamic dilution $(=n)^{b}$ & $3.4 \pm 0.6$ & $1.8 \pm 0.2$ & $1.2 \pm 0.2$ \\
\hline \multicolumn{4}{|c|}{ Humidity dependence } \\
\hline \multicolumn{4}{|c|}{ Experimental results: fitted to $\mathrm{y}=a /(\mathrm{x}+b)$} \\
\hline$a(\mathrm{ncps} \mathrm{mmol} / \mathrm{mol})^{c}$ & $1512 \pm 98$ & $538 \pm 58$ & $257 \pm 35$ \\
\hline$b(\mathrm{mmol} / \mathrm{mol})^{c}$ & $13.1 \pm 0.8$ & $9.5 \pm 1.0$ & $6.0 \pm 0.8$ \\
\hline \multicolumn{4}{|c|}{ Estimations from kinetic parameters } \\
\hline$k_{6}\left(10^{-9} \mathrm{~cm}^{3} \text { molecule }{ }^{-1} \mathrm{~s}^{-1}\right)^{d}$ & 1.6 & 1.4 & 1.3 \\
\hline$k_{-6}\left(10^{-11} \mathrm{~cm}^{3} \text { molecule }{ }^{-1} \mathrm{~s}^{-1}\right)^{d}$ & 1.0 & 2.9 & 5.0 \\
\hline$c\left(=k_{6} / k_{-6}[\mathrm{HCHO}]^{e}\right)$ & 3728 & 1125 & 606 \\
\hline$m / n$ & 2.6 & 2.7 & 2.8 \\
\hline$c / a$ & 2.5 & 2.1 & 2.4 \\
\hline
\end{tabular}

a Error limits represent $2 \sigma$ of continuously observed ion signals at $m / z 31$.

$b$ Error limits represent $95 \%$ confidence levels by $t$-test.

c Error limits represent $2 \sigma$.

$d$ Data taken from Fig. 2 of Hansel et al. (1997).

e $[\mathrm{HCHO}]=23.3$ ppbv.

strength $\left(\mathrm{V} \mathrm{cm}^{-1}\right)$ and $N$ is the buffer gas number density (molecule $\mathrm{cm}^{-3}$ ) (instrumental parameters are given in Table 1). In the field measurements, the $E / N$ value was set to $108 \mathrm{Td}$. Source current, $U_{4}, U_{5}, U_{1}$, and $U_{\mathrm{NC}}$, of the PTRMS instrument were $8.0 \mathrm{~mA}, 95 \mathrm{~V}, 90 \mathrm{~V}, 50 \mathrm{~V}$, and $5.8 \mathrm{~V}$, respectively. Values of transmission of the ions at $m / z 21,31$, 33 , and 47 through the mass filter used in our instrument were $0.557,0.671,0.693$, and 0.836 , respectively.

Detection sensitivities of $\mathrm{HCHO}$ in dry conditions $\left(\left[\mathrm{H}_{2} \mathrm{O}\right]\right.$ $<1 \mathrm{mmol} / \mathrm{mol}$ ) were determined by two methods: (1) a direct introduction method and (2) a dynamic dilution method. In the direct introduction method, the inlet of the PTR-MS was connected directly to a standard gas mixture of $\mathrm{HCHO} / \mathrm{N}_{2}$ (1.02 ppmv). In the dynamic dilution method, $\mathrm{HCHO}$ at 525 parts per billion by volume (ppbv) mixing ratios was produced by a dynamic dilution of the standard gas with zero air generated by a zero air supply (Model 111, Thermo Environmental Instruments Inc., Franklin, MA, USA). The dynamic dilution system was custom-built and consisted of two mass flow controllers (AERA, FC-795C @ 10 sccm (air) and
FC-795C @ 5 slm (air), Advanced Energy Japan, Tokyo, Japan). The mass flow controllers were calibrated by film flow meters (Humonics Optiflow 420, Agilent Technologies, Santa Clara, CA, USA and VP-40, HORIBASTEC, Kyoto, Japan, respectively). The uncertainty of the derived concentration was typically $3 \%$.

To vary the humidity in the sample, a humidity controller (SRG-1R-10, SHINYEI, Kobe, Japan) was connected to the line carrying zero air. The water vapor concentration of the moist air was estimated using an optical chilled mirror hygrometer (General Eastern, 1311DR-SR, GE Sensing, Billerica, MA, USA) between the humidity controller and the PTR-MS. The hygrometer was removed from the analysis line for measuring the detection sensitivities of $\mathrm{HCHO}$. The moist air produced by the humidity controller was mixed with the HCHO standard gas in the dynamic dilution system and then introduced into the PTR-MS. We did not introduce the HCHO standard gas into the humidity controller because a large solubility into water is expected for HCHO (Zhou and Mopper, 1990). 
The humidity dependence of the background signals at $\mathrm{m} / \mathrm{z}$ 31,33 , and 47 was investigated in a separate experiment on zero air without added HCHO standard gas; no significant humidity dependence was found under these conditions.

Standard gases of $\mathrm{HCHO}, \mathrm{CH}_{3} \mathrm{OH}$, and $\mathrm{C}_{2} \mathrm{H}_{5} \mathrm{OH}$ balanced with nitrogen (1.02 ppmv, $10.8 \mathrm{ppmv}$, and $9.56 \mathrm{ppmv}$, respectively, from Takachiho, Tokyo, Japan) and high-purity $\mathrm{N}_{2}$ gas (>99.99995\%, from Japan Fine Products, Kawasaki, Japan) were used as received. The HCHO concentrations in the standard gas were determined by the gas supplier (Takachiho) with precision of approximately 5\%. However, the $\mathrm{HCHO}$ concentrations might decline, resulting in an underestimation of the HCHO detection sensitivity. Since the gas supplier guarantees an accuracy of $20 \%$ within 3 months, we used the standard gas within $100 \mathrm{~d}$ of receipt. In particular, between determinations of detection sensitivity in dry conditions (using the direct introduction method) conducted 30 and $100 \mathrm{~d}$ after the supplier tested the gas, we did not observe a significant decay in $\mathrm{HCHO}$ concentration in the standard gas.

Methyl hydroperoxide, $\mathrm{CH}_{3} \mathrm{OOH}$, was synthesized by methylation of hydrogen peroxide (Vaghjiani and Ravishankara, 1989). A reference mass spectrum of the $\mathrm{CH}_{3} \mathrm{OOH}$ was obtained from the sample vapor. For methanol, ethanol, 2-propanol, n-butanol, and iso-butanol, reference mass spectra were obtained from vapors prepared by injecting liquid chemicals into a 5-liter Pyrex glass vessel (Aoki et al., 2007). Dimethyl sulfate (>95\%), hydrogen peroxide $(\sim 30 \%)$, potassium hydroxide ( $>85 \%$ ), sulphuric acid $(47 \%)$, diethyl ether $(>99.5 \%)$, and sodium sulfate $(99.9 \%)$ were used for synthesis of $\mathrm{CH}_{3} \mathrm{OOH}$, and methanol $(>99.8 \%)$, ethanol (>99.8\%), 2-propanol (>99.9\%), n-butanol (>99\%), and isobutanol (>99\%) were used to obtain preliminary reference mass spectra; these chemicals were all purchased from Wako Chemicals, Osaka, Japan.

\subsection{Field measurement site and PTR-MS setup}

Field measurements were made at the summit of Mount Tai in China $\left(36.25^{\circ} \mathrm{N}, 117.10^{\circ} \mathrm{E}, 1534 \mathrm{~m}\right.$ a.s.l.). Mount Tai is an isolated single mountain in the North China plain (Gao et al., 2005). The summit overlooks the city of Tai' an (population: 500000 ), $10 \mathrm{~km}$ to the south. The city of Ji'nan (capital of Shandong province, population: 2.1 million) is situated $60 \mathrm{~km}$ to the north. There are many tourists on the mountain in the summer months (June-September); consequently, local emissions from small restaurants and temples are sometimes significant pollution sources. The PTR-MS was housed in a room on the ground floor of the station. The inlet was located approximately $10 \mathrm{~m}$ above the ground. A 1/4" Teflon line $(4.0 \mathrm{~mm}$ ID and approximately $15 \mathrm{~m}$ long) was used as a sample line. The sample air was pumped at the flow rate of $2 \mathrm{~L} \mathrm{~min}^{-1}$, with an estimated residence time of $6 \mathrm{~s}$ in the flow tube. An in-line particulate filter was used to prevent particles from entering the instrument. The voltage of the drift tube $\left(U_{\text {drift }}\right)$ was set to $400 \mathrm{~V}$ and data were continuously

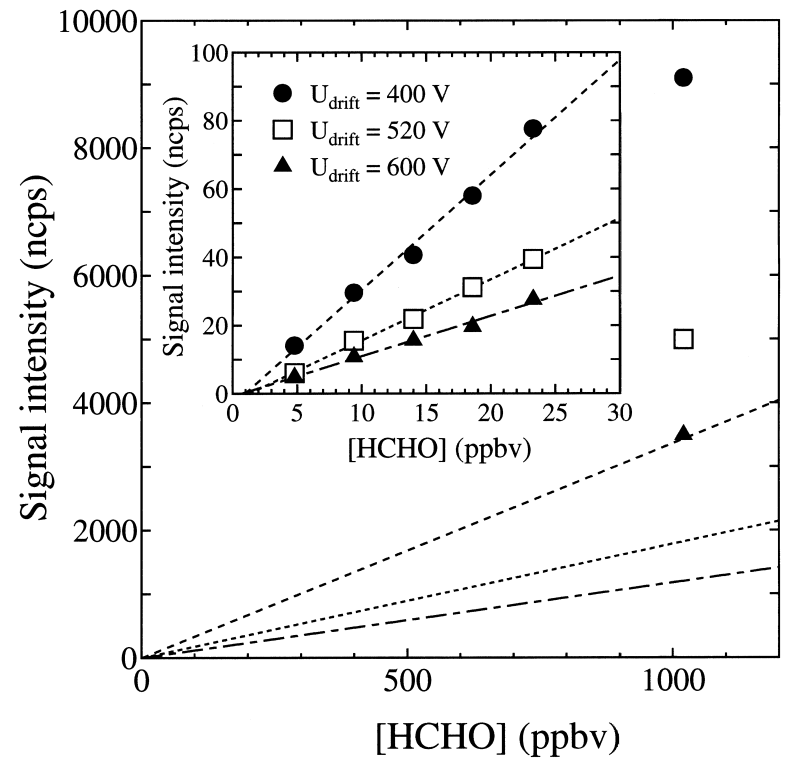

Fig. 3. Plots of normalized PTR-MS signal intensities at $m / z 31$ vs. the $\mathrm{HCHO}$ concentrations at three drift tube $E / N$ ratios in dry conditions. Inset: data obtained from the dynamic dilution method, with least-squares fit lines. Main figure: data obtained from the direct introduction method, with fit lines extrapolated from the dynamic dilution method.

recorded during 12-30 June 2006 using the PTR-MS instrument's scan mode (from $m / z 17$ to $m / z 300$ with $0.1 \mathrm{~s}$ data collection at each step). Since the background signals at $\mathrm{m} / \mathrm{z}$ 31 were $16.0 \pm 2.1(2 \sigma)$ ncps (normalized count per s; normalized to the $\mathrm{H}_{3} \mathrm{O}^{+}$intensity of $10^{6} \mathrm{cps}$ ), detection limits at $S / N=2$ were estimated to be $0.2-0.5 \mathrm{ppbv}$ for a typical 5 -s integration $(0.1 \mathrm{~s} \times 50$ scans during $30 \mathrm{~min})$, depending on the ambient humidity $(5.1-27.4 \mathrm{mmol} / \mathrm{mol})$.

\subsection{MAX-DOAS instrument setup}

The MAX-DOAS system used in this work consisted of two main parts: a telescope unit placed outdoors and an indoor spectrograph (Andor Technology, Shamrock SR-303iA) coupled with a two-dimensional CCD (charge coupled device) array detector (Andor Technology, DV-420A-OE; $1024 \times 256$ pixels). The telescope unit had five telescopes; all were directed south, but their elevation angles (ELs) differed; they were fixed at $-5^{\circ}, 5^{\circ}, 10^{\circ}, 20^{\circ}$, and $30^{\circ}$. The telescope with $-5^{\circ}$ EL looked down from Mount Tai toward Tai' an city, located at the foot of the mountain (126 ma.s.1.). The field of view (FOV) was estimated to be $<1^{\circ}$ for each telescope. To acquire a reference spectrum with the same instrument line shape as that of off-axis measurements, a mirror was periodically inserted into the FOV of each telescope, directing the viewing path to the zenith sky. A 6-min zenithsky measurement was made automatically every $30 \mathrm{~min}$. To achieve simultaneous multi-track acquisitions, the sunlight collected by the telescopes was directed to a spectrograph 


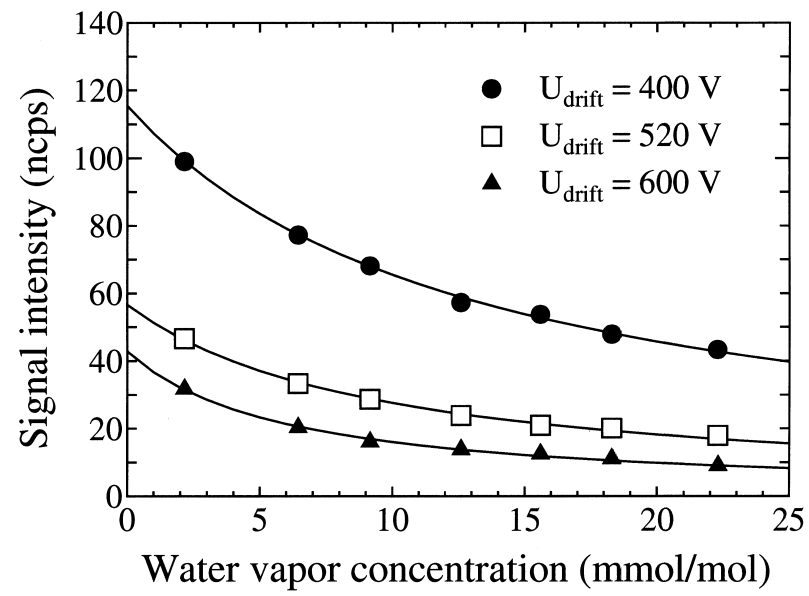

Fig. 4. Plots of signal intensities at $m / z 31$ vs. water vapor concentrations, at three drift tube $E / N$ ratios. $[\mathrm{HCHO}]=23.3 \mathrm{ppbv}$. The water vapor concentrations in the sample were determined from the best-fit curve (dashed line) shown in Fig. 1. Fit lines represent leastsquares fitting to Eq. (4) (See discussion of Eqs. (3) and (4); the yaxis of this figure corresponds to the left-hand side of Eq. (3), while the $\mathrm{x}$-axis corresponds to $\left.\left[\mathrm{H}_{2} \mathrm{O}\right]_{\text {sample }}\right)$.

slit (30 $\mu \mathrm{m}$ width) via a 3-m fiber bundle cable with a fiveway input. The five measured spectra were simultaneously projected onto the $\mathrm{CCD}$ detector, with a 30-pixel track for each spectrum. The spectrograph employed a Czerny-Turner optical layout with a focal length of $303 \mathrm{~mm}$ and a planeruled grating with a groove frequency of 1200 lines $\mathrm{mm}^{-1}$ at a blaze wavelength of $300 \mathrm{~nm}$. The CCD detector was cooled to $-50^{\circ} \mathrm{C}$ to reduce thermal noise. Two wavelength regions, $310-377 \mathrm{~nm}$ and $425-490 \mathrm{~nm}$, were measured in alternating periods of $15 \mathrm{~min}$ each. The spectral resolution (FWHM) was about $0.2-0.3 \mathrm{~nm}$ for the wavelength regions discussed below (325-367 nm), according to wavelength calibration using a high-resolution solar spectrum reported by Kurucz et al. (1984).

We used a DOAS spectral fitting algorithm identical to that described by Irie et al. (2007) except as stated below. The spectral fitting window of $325-367 \mathrm{~nm}$ was analyzed to derive the differential slant column densities $(\triangle \mathrm{SCDs})$ of $\mathrm{HCHO}$ and the oxygen dimer $\left(\mathrm{O}_{2}-\mathrm{O}_{2}\right.$ or $\left.\mathrm{O}_{4}\right)$, simultaneously. Over $325-367 \mathrm{~nm}$, a slowly changing structure, mainly due to Rayleigh and Mie scattering, and a wavelength-dependent offset were approximated by fourthand second- order polynomials, respectively. The components considered in the spectral fitting are $\mathrm{HCHO}, \mathrm{O}_{4}$, $\mathrm{O}_{3}, \mathrm{NO}_{2}$, the Ring effect, and the undersampling effect. We adopted $\mathrm{HCHO}$ absorption cross-section data from Meller and Moortgat (2000). The resulting residuals of the differential optical depth were generally below $1 \times 10^{-3}$, which corresponds to an HCHO $\triangle \mathrm{SCD}$ error of $\sim 5 \times 10^{14}$ molecules $\mathrm{cm}^{-2}$ throughout the field measurement period.
We next applied an aerosol retrieval algorithm (Irie et al., 2007 ) to the derived $\mathrm{O}_{4} \Delta \mathrm{SCD}$ values to determine the boxair-mass-factor $\left(A_{b o x}\right)$ vertical profile for each 30-min cycle. The algorithm utilizes the optimal estimation method (Rodgers, 2000) and a radiative transfer model, MCARaTS (Iwabuchi, 2006). In the radiative transfer modeling, we assumed a single scattering albedo of 0.90 , an asymmetry parameter of 0.65 , and a surface albedo of 0.10 . The overall intrinsic error in the retrieved aerosol optical depth was assumed to be $30 \%$, according to the estimate by Irie et al. (2007).

Using the calculated $A_{\text {box }}$ vertical profile, the $\mathrm{HCHO}$ $\triangle \mathrm{SCD}$ values were converted to a vertical profile by applying the nonlinear least-squares fitting method to the $\mathrm{HCHO}$ $\triangle \mathrm{SCD}$ values. For this conversion, a retrieval algorithm very similar to the aerosol retrieval algorithm (Irie et al., 2007) was applied to the HCHO $\triangle \mathrm{SCD}$ values. The algorithm is applicable to the HCHO retrieval because the nonlinearity of the forward model should be much lower than that of the aerosol retrievals. The lowest altitude of the vertical profile was set to $126 \mathrm{~m}$ a.s.l., corresponding to the surface level at Tai'an. The mean HCHO volume mixing ratios in the layer $1-2 \mathrm{~km}$ above the surface (referred to as $\mathrm{HCHO}(1-$ $2 \mathrm{~km}$ ) below) were compared to PTR-MS HCHO values. The layer corresponds to the layer $1126-2126 \mathrm{~m}$ a.s.l., the center of which is close to the mountaintop elevation. For each retrieval, the random error was estimated from the retrieval covariance matrix, according to Rodgers (2000). In this estimate, we used the measurement covariance matrix constructed from the residual that arose in fitting the $\mathrm{HCHO}$ $\triangle \mathrm{SCD}$ values, because it was much larger than the HCHO $\triangle \mathrm{SCD}$ error. The systematic error was estimated by making additional retrievals, for which the aerosol optical depth varied by $\pm 30 \%$. The mean values of the random and systematic errors estimated in this way are 0.64 and $0.17 \mathrm{ppbv}$, respectively, for the data set that is compared to PTR-MS measurements below.

\section{Results and discussion}

We considered the relative intensity of $\mathrm{H}_{3} \mathrm{O}^{+} \cdot \mathrm{H}_{2} \mathrm{O}$ to $\mathrm{H}_{3} \mathrm{O}^{+}$ (M37/M19) as a function of water vapor concentration $(\mathrm{mmol} / \mathrm{mol})$ in the sample air to examine whether the correction factors for $\mathrm{HCHO}$ determined in laboratory experiments could be applied to the field data (Fig. 1). There is obvious tight correlation, and the ratios obtained in the field measurements agreed closely with laboratory results. The relationship was similar to that reported by Ammann et al. (2006). The M37/M19 ratio does not approach zero as ambient water vapor concentrations approach zero because water vapor from the ion source exists in the drift tube in addition to water vapor from the sample air. 


\subsection{Laboratory calibration}

\subsubsection{Detection sensitivities under dry conditions}

Mass spectra were obtained via the direct introduction method and the dynamic dilution method. For the spectra obtained by the direct introduction method, the $\mathrm{HCHO}$ concentration in the standard gas used was $1.02 \mathrm{ppmv}$; for the dynamic dilution spectra, the standard gas mixture was diluted with zero air in the ratio of $1: 43$; i.e. $[\mathrm{HCHO}]=23.3$ ppbv. The mass spectra were taken with three different $E / N$ ratios. In all $E / N$ conditions, ion peaks of the protonated $\mathrm{HCHO}$ were the most strongly observed at $m / z 31$ (Fig. 2). In addition to these protonated peaks, the protonated $\mathrm{HCHO}$ dimer, $\mathrm{MMH}^{+}$, was observed at $m / z 61$, especially with lower $E / N$ conditions in the drift tube.

Although the mass spectra obtained by the two $\mathrm{HCHO}$ introduction methods were similar, we found that the signal intensities of $\mathrm{MH}^{+}$were not proportional to the concentrations of HCHO introduced. Though signal intensity vs. $\mathrm{HCHO}$ concentration relationships were linear among various dynamic dilutions within each $E / N$ condition, extrapolated values from these data were not in agreement with the values obtained from the direct introduction method (Fig. 3). The detection sensitivities normalized to the $\mathrm{H}_{3} \mathrm{O}^{+}$intensity of $10^{6} \mathrm{cps}$ obtained in the direct introduction method were $8.9 \pm 0.3,4.9 \pm 0.2$, and $3.4 \pm 0.2 \mathrm{ncps} / \mathrm{ppbv}$ at $U_{\mathrm{drift}}=400,520$, and $600 \mathrm{~V}$, respectively. The sensitivities obtained in the dynamic dilution method were 2.6-2.8 times lower $(\mathrm{m} / \mathrm{n}$ ratio in Table 1) than those obtained in the direct introduction method, and were $3.4 \pm 0.6,1.8 \pm 0.2$, and $1.2 \pm 0.2 \mathrm{ncps} / \mathrm{ppbv}$ at $U_{\mathrm{drift}}=400,520$, and $600 \mathrm{~V}$, respectively (Table 1).

If the difference in the detection sensitivities is caused by saturation of the ion signal in the direct introduction method because the concentration of the $1.02 \mathrm{ppmv}$ standard used in the direct introduction method is close to the upper limit of the linear dynamic range of the PTR-MS, the detection sensitivities from the direct introduction method should be lower than those from the dynamic dilution method. However, the reverse was observed. This suggests that there may have been losses of HCHO in the lines and/or a mass flow controller, which were used in the dynamic dilution method. We assume that the detection sensitivities obtained in the direct introduction method are better suited to accurate field measurement.

The detection sensitivities for $\mathrm{HCHO}$ calculated from Eq. (1) were 9.1, 7.0, and 6.1 ncps/ppbv at $U_{\text {drift }}=400,520$, and $600 \mathrm{~V}$, respectively, assuming the typical rate constant of reaction (R6) $\left(k=2 \times 10^{-9} \mathrm{~cm}^{3}\right.$ molecule $\left.{ }^{-1} \mathrm{~s}^{-1}\right)$. The calculated value at $U_{\mathrm{drift}}=400 \mathrm{~V}, 9.1 \mathrm{ncps} / \mathrm{ppbv}$, was very close to the calibrated value, $8.9 \pm 0.3 \mathrm{ncps} / \mathrm{ppbv}$, but differences between the calculated and calibrated values for higher $U_{\mathrm{drift}}$ become significant. This suggests that the backward reaction (R-6) becomes important, especially at high $E / N$ in the drift tube. Steinbacher et al. (2004) compared the HCHO

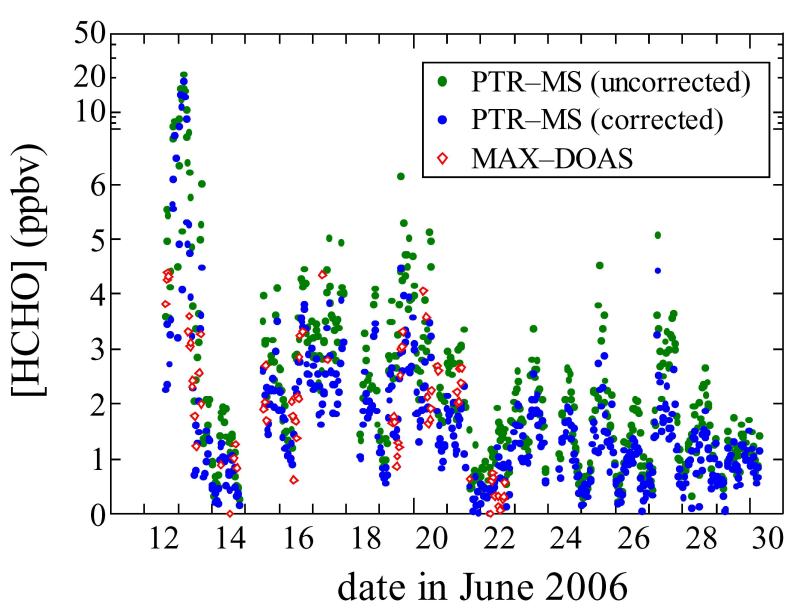

Fig. 5. Time variation of HCHO mixing ratios measured by PTRMS and MAX-DOAS during a 19-day field campaign at Mount Tai in China. Uncorrected PTR-MS data points represent HCHO mixing ratios calculated from uncorrected M31 signals; corrected PTRMS data points were calculated from M31 signals from which fragment ion signals at $m / z 31$ from methyl hydroperoxide and alcohols (methanol and ethanol) were subtracted.

(produced with a permeation source and diluted with zero air) concentrations measured by PTR-MS with those measured by a Hantzsch monitor in dry conditions. The HCHO concentrations obtained by PTR-MS were calculated using $k=2 \times 10^{-9} \mathrm{~cm}^{3}$ molecule $\mathrm{s}^{-1}$. Steinbacher et al. (2004) found that the PTR-MS, operated with a drift energy $\left(\mathrm{KE}_{\mathrm{cm}}\right)$ of $0.17 \mathrm{eV}$, detected $21 \%$ of the $\mathrm{HCHO}$ measured by the Hantzsch monitor. Our result, based on the dynamic dilution method at $U_{\text {drift }}=520 \mathrm{~V}$, was $26 \%$, and is in good agreement with Steinbacher et al. (2004)

\subsubsection{Humidity dependence}

The dependence of the detection sensitivity on humidity in the sample air was measured only for the dynamic dilution method. When tested at vapor concentrations of $2-$ $23 \mathrm{mmol} / \mathrm{mol}$, the ion signal at $\mathrm{m} / z 31$ decreased with increasing humidity in all $E / N$ conditions (Fig. 4). Steinbacher et al. (2004), based on the rate constants for the forward and backward protonation reactions (R6) and (R-6) (Hansel et al., 1997), estimated a reduction of sensitivity down to 0.37 , compared to dry conditions, at a water vapor concentration of $20 \mathrm{mmol} / \mathrm{mol}$ in the sample, and with a drift energy $\left(\mathrm{KE}_{\mathrm{cm}}\right)$ of $0.17 \mathrm{eV}$. The ratio of the detection sensitivity at a water vapor concentration of $22.3 \mathrm{mmol} / \mathrm{mol}$ to that at $2.2 \mathrm{mmol} / \mathrm{mol}$ was 0.39 at $U_{\mathrm{drift}}=520 \mathrm{~V}$ in the present study. Note that our experimentally determined results are consistent with the calculation-based values of Steinbacher et al. (2004). 

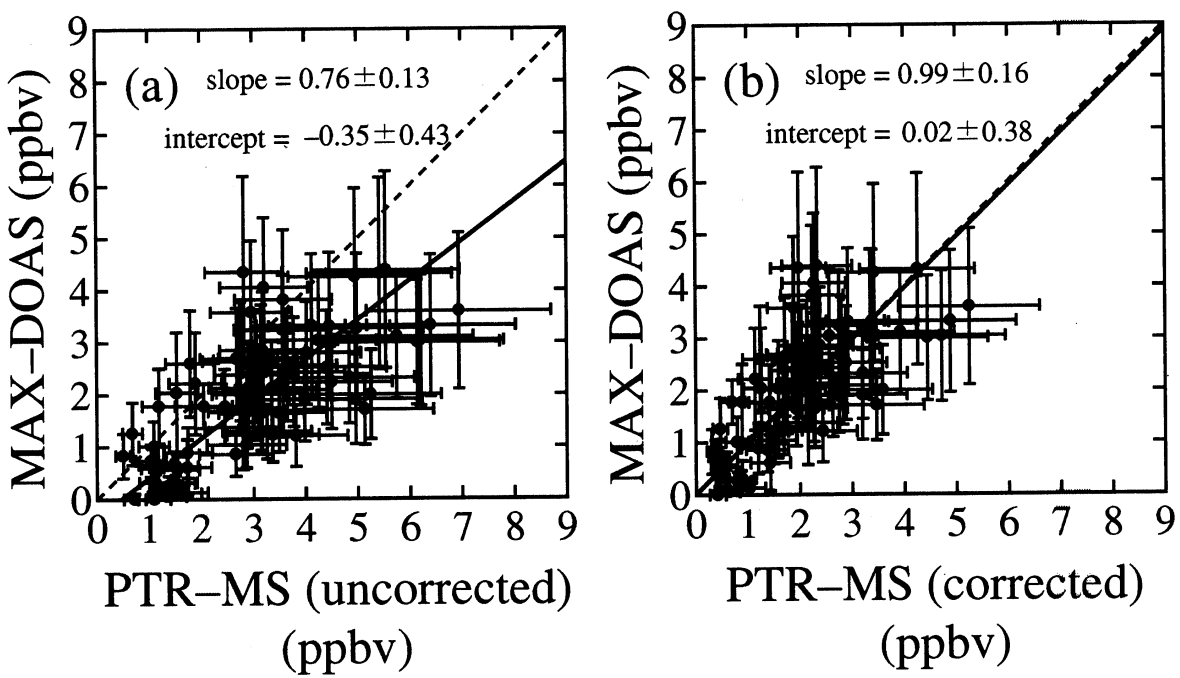

Fig. 6. Scatterplots of HCHO mixing ratios obtained by PTR-MS and MAX-DOAS. Dotted lines show x=y line. (a) The HCHO mixing ratio was obtained by using uncorrected M31 signals from PTR-MS data. (b) The HCHO mixing ratio was obtained by using M31 signals from PTR-MS data, from which fragment ion signals at $\mathrm{m} / z 31$ from methyl hydroperoxide and alcohols (methanol and ethanol) were subtracted. The regression lines (solid lines) were obtained by the reduced-major-axis (RMA) regression method.

Next, we used a kinetic approach to evaluate the humidity dependence of the detection sensitivity of HCHO. In the drift tube, as $\mathrm{HCHO}$ reacts with $\mathrm{H}_{3} \mathrm{O}^{+}$(R6), the concentration of the protonated $\mathrm{HCHO}$ increases until the rate of the backward reaction $(\mathrm{R}-6)$ balances the forward rate. If we assume that the equilibrium between $\mathrm{H}_{3} \mathrm{O}^{+}, \mathrm{HCHO}, \mathrm{HCHO} \cdot \mathrm{H}^{+}$, and $\mathrm{H}_{2} \mathrm{O}$ is reached by the end of the drift tube, the relationship between concentrations of $\mathrm{H}_{3} \mathrm{O}^{+}, \mathrm{HCHO}, \mathrm{HCHO} \cdot \mathrm{H}^{+}$, and $\mathrm{H}_{2} \mathrm{O}$ can be given as follows:

$$
\frac{\left[\mathrm{HCHO} \bullet \mathrm{H}^{+}\right]\left[\mathrm{H}_{2} \mathrm{O}\right]}{\left[\mathrm{H}_{3} \mathrm{O}^{+}\right][\mathrm{HCHO}]}=\frac{k_{6}}{k_{-6}}=K
$$

where $k_{6}$ and $k_{-6}$ represent rate constants of the forward and backward reactions (R6) and (R-6), respectively, and $K$ is the equilibrium constant. Equation (1) can be modified as follows:

$$
\frac{\left[\mathrm{HCHO} \bullet \mathrm{H}^{+}\right]}{\left[\mathrm{H}_{3} \mathrm{O}^{+}\right]} \times 10^{6}(\mathrm{ncps})=\frac{k_{6}}{k_{-6}} \cdot \frac{[\mathrm{HCHO}](\mathrm{ppbv})}{\left[\mathrm{H}_{2} \mathrm{O}\right](\mathrm{mmol} / \mathrm{mol})}
$$

The water vapor concentration in the drift tube can be divided into contributions from the ion source and the sample, i.e. $\left[\mathrm{H}_{2} \mathrm{O}\right]=\left[\mathrm{H}_{2} \mathrm{O}\right]_{\text {ion source }}+\left[\mathrm{H}_{2} \mathrm{O}\right]_{\text {sample }}$. Therefore, the humidity dependence of signal intensity can be fitted to an expression of the type

$y=\frac{a}{x+b}$

where

$a \equiv \frac{k_{6}}{k_{-6}}[\mathrm{HCHO}]$

and

$b \equiv\left[\mathrm{H}_{2} \mathrm{O}\right]_{\text {ion source }}$
The values of $k_{6}$ and $k_{-6}$ were reported as a function of the energy in the drift tube: respectively, they were approximately $1.6 \times 10^{-9}$ and $1.0 \times 10^{-11}\left(U_{\text {drift }}=400 \mathrm{~V}\right)$, $1.4 \times 10^{-9}$ and $2.9 \times 10^{-11}\left(U_{\text {drift }}=520 \mathrm{~V}\right)$, and $1.3 \times 10^{-9}$ and $5.0 \times 10^{-11}\left(U_{\text {drift }}=600 \mathrm{~V}\right)$, in units of $\mathrm{cm}^{3}$ molecule ${ }^{-1} \mathrm{~s}^{-1}$ (Hansel et al., 1997). Empirical values of $c\left(c=k_{6} / k_{-6}\right.$ [HCHO]) should be equal to the fitting parameter, $a$, in Eq. (4), but the value of $c$ was 2.1-2.5 times higher than the value of $a$ (see $c / a$, Table 1). This suggests losses of $\mathrm{HCHO}$ in the dynamic dilution system; we suggest that this is closely related to the differences in detection sensitivity observed in dry conditions. The values of $c / a$ obtained from the kinetic parameters were very close to values of $m / n$, the ratio of experimental detection sensitivities obtained by the direct introduction $(=m)$ and dynamic dilution $(=n)$ methods. The average ratio $(m / n) /(c / a)$ was calculated to be $1.2 \pm 0.3$, where the indicated error limits represent $95 \%$ confidence levels by $t$-test, and the values of $m / n$ and $c / a$ were identical within the error limits. Therefore, we conclude that the detection sensitivity of $\mathrm{HCHO}$ obtained in the dynamic dilution method should be multiplied by $m / n$, that is, the normalized detection sensitivity, $S$ (ncps/ppbv), of HCHO and its humidity dependence at each $E / N$ condition can be described as follows:

$S=\frac{m}{n} \cdot \frac{a}{\left[\mathrm{H}_{2} \mathrm{O}\right]_{\text {sample }}+b} \cdot \frac{1}{23.3}$

where ion counts are divided by 23.3 because the humidity dependence was measured with $[\mathrm{HCHO}]=23.3 \mathrm{ppbv}$ in the dynamic dilution method. The uncertainty of the calibrated data by this method was taken as $\pm 25 \%$. This value was the largest among the errors in $m$ and $n$ ( $\pm 3-6 \%$ and $\pm 11-16 \%$, 
respectively; see Table 1), errors originating from fitting to Eq. (3) ( $\pm 9-18 \%$; errors in the fitting, $\sigma_{y}$, are estimated from $\left.\sigma_{y}^{2}=(\delta \mathrm{a} / \mathrm{a})^{2}+\left(\delta \mathrm{b} /\left(\left[\mathrm{H}_{2} \mathrm{O}\right]_{\text {sample }}+\mathrm{b}\right)\right)^{2}\right)$, and the error in the average of the ratio $(m / n) /(c / a)( \pm 25 \%)$.

The fitting parameter, $b$, represents the water vapor concentration from the ion source; it varied from 6 to $13 \mathrm{mmol} / \mathrm{mol}$. The reason for the poor agreement between $b$ values in different $E / N$ conditions is not known. This poor agreement may be because the forward and backward reactions (R6) and (R-6) do not come to equilibrium by the end of the drift tube.

\subsubsection{Possible interference in M31 signals}

Steinbacher et al. (2004) found an inconsistency between PTR-MS and the Hantzsch monitor for ambient HCHO measurements. The disagreement may be partly explained by the humidity dependence of the detection sensitivity of HCHO, because Steinbacher et al. (2004) determined the HCHO concentrations by calculation. They observed different patterns by the two methods in diurnal variations of $\mathrm{HCHO}$, and suggested the possibility of interferences from other compounds in the sample air. The possible interference of fragment ions from methyl hydroperoxide $\left(\mathrm{CH}_{3} \mathrm{OOH}\right)$ was discussed, but the inconsistency was not fully explained.

In the present study, we investigated a reference mass spectrum of $\mathrm{CH}_{3} \mathrm{OOH}$. We observed the ion signals at $\mathrm{m} / \mathrm{z}$ 31 as well as those of the protonated methyl hydroperoxide at $m / z$ 49. The M $31 / \mathrm{M} 49$ ratio was $0.92 \pm 0.06$ at $U_{\text {drift }}=400 \mathrm{~V}$. Fragmentation is significant for the protonated methyl hydroperoxide, probably because an $\mathrm{H}_{2} \mathrm{O}$ can be easily eliminated from protonated methyl hydroperoxide to produce methoxy cations.

In addition, ion signals at $m / z 31$ were observed in the analysis of methanol and ethanol by PTR-MS. The ion responsible is presumably $\mathrm{CH}_{2} \mathrm{OH}^{+}$, which has the same mass as protonated HCHO. The M31/M33 and M31/M47 ratios were investigated at various mixing ratios from 20 to $100 \mathrm{ppbv}$, but remained constant at $0.0073 \pm 0.0002$ and $0.045 \pm 0.004$, respectively. Ion signals at $m / z 31$ were not observed for propanol and butanol, probably because an $\mathrm{H}_{2} \mathrm{O}$ can be easily eliminated from protonated propanol and butanol to produce corresponding alkyl cations (Spanel and Smith, 1997), which do not have the structure of $-\mathrm{CH}_{2} \mathrm{OH}$.

3.2 Field measurements and comparison with MAXDOAS

For the purpose of intercomparison between PTR-MS and MAX-DOAS, PTR mass spectra were averaged over each 30-min period. The uncorrected concentration of $\mathrm{HCHO}$ (ppbv) was determined as follows:

$[\mathrm{HCHO}]=I_{31} / S_{400 \mathrm{~V}}$ where $I_{31}$ represents the ion intensity at $\mathrm{m} / z 31$ normalized to the $\mathrm{H}_{3} \mathrm{O}^{+}$intensity of $10^{6} \mathrm{cps}$, and

$S_{400 \mathrm{~V}}=\frac{169}{\left[\mathrm{H}_{2} \mathrm{O}\right]_{\text {sample }}+13.1}$

Error limits of the PTR-MS data were calculated by the following equation:

$$
\frac{\delta[\mathrm{HCHO}]}{[\mathrm{HCHO}]}=\sqrt{\left(\frac{\delta S_{400 \mathrm{~V}}}{S_{400 \mathrm{~V}}}\right)^{2}+\left(\frac{\sqrt{I_{31}}}{I_{31}}\right)^{2}}
$$

where the value of 0.25 was used for $\delta S_{400 \mathrm{~V}} / S_{400 \mathrm{~V}}$ and $\sqrt{I_{31}}$ was used as the uncertainty of $I_{31}$.

The mixing ratios observed during field measurements typically varied from 0 to $6 \mathrm{ppbv}$, except during the night of 12 June (Fig. 5). Diurnal variations, with a daytime maximum and nighttime minimum, were observed during 24 and 28 June. In addition, the $\mathrm{HCHO}$ concentrations were low on rainy days (e.g. from the night of 13 June to the morning of 14 June).

We compared HCHO mixing ratios determined by MAXDOAS against those determined by PTR-MS, determining the slope and intercept of the regression line using the reduced-major-axis (RMA) regression method (Ayers, 2001). We used this method rather than the standard linear least squares regression because both data sets are measured variables, and thus are both subject to error. The RMA regression is a bilinear method that allows for errors in both variables. Without correction, most determinations of HCHO mixing ratios by PTR-MS are higher than those by MAX-DOAS (Fig. 6a). The best-fit line by the RMA regression method is largely shifted toward the PTR-MS-derived HCHO concentrations, providing a slope of $0.76 \pm 0.13$ and an intercept of $-0.35 \pm 0.43$. Error limits of the slope and intercept represent $95 \%$ confidence levels.

Subsequently, the HCHO PTR-MS measurements were corrected by subtracting the fragment ions contributed by $\mathrm{CH}_{3} \mathrm{OOH}$ from the ion signals at $m / z 31$, assuming that the observed ion signals at $\mathrm{m} / z, 49$ are attributable to $\mathrm{CH}_{3} \mathrm{OOH}$. However, this did not greatly improve the agreement between PTR-MS and MAX-DOAS (slope $=0.78 \pm 0.13$; intercept $=-0.29 \pm 0.42$ ). The averaged ion signals during the field measurements were $109,894,404$, and $8 \mathrm{cps}$ for $\mathrm{m} / z 31$, 33,47 , and 49 , respectively; the contribution of fragments from methanol and ethanol to the signals at $\mathrm{m} / \mathrm{z} 31$ was not negligible. The PTR-MS HCHO data were corrected again by subtracting the contributions of the fragment ions from methanol and ethanol from the ion signals at $m / z 31$, assuming that the observed ion signals at $m / z 33$ and 47 were attributable to methanol and ethanol, respectively, i.e.

$[\mathrm{HCHO}]_{\mathrm{corr}}=I_{31}^{\text {corr }} / S_{400 \mathrm{~V}}$ 
where $I_{31}^{\text {corr }}$ is $I_{31}-\alpha_{49} \times I_{49}-\alpha_{33} \times I_{33}-\alpha_{47} \times I_{47}$ and $\alpha_{\mathrm{X}}$ represents a ratio of M31/MX. Error limits of the PTR-MS data were derived by the following equation:

$$
\frac{\delta[\mathrm{HCHO}]}{[\mathrm{HCHO}]}=\sqrt{\left(\frac{\delta S_{400 \mathrm{~V}}}{S_{400 \mathrm{~V}}}\right)^{2}+\left(\frac{\delta I_{31}^{\text {corr }}}{I_{31}^{\text {corr }}}\right)^{2}}
$$

where

$$
\begin{aligned}
\left(\delta I_{31}^{\text {corr }}\right)^{2}= & \left(\sqrt{I_{31}}\right)^{2}+ \\
& \sum_{\mathrm{X}}\left[\left\{\left(\frac{\sqrt{I_{\mathrm{X}}}}{I_{\mathrm{X}}}\right)^{2}+\left(\frac{\delta \alpha_{\mathrm{X}}}{\alpha_{\mathrm{X}}}\right)^{2}\right\}\left(\alpha_{\mathrm{X}} \cdot I_{\mathrm{X}}\right)^{2}\right]
\end{aligned}
$$

Values of $0.25,0.07,0.03$, and 0.09 were used for $\delta S_{400 \mathrm{v}} / S_{400 \mathrm{v}}, \delta \alpha_{49} \mathrm{v} \alpha_{49}, \delta \alpha_{33} \mathrm{v} \alpha_{33}$, and $\delta \alpha_{47} \mathrm{v} \alpha_{47}$, respectively, and $\sqrt{I_{\mathrm{X}}}$ was used as the uncertainty of $I_{\mathrm{X}}$.

After these corrections were applied, the PTR-MSderived $\mathrm{HCHO}$ mixing ratios were decreased accordingly (Figs. 5, 6b). The corrections greatly improved the agreement between MAX-DOAS and PTR-MS. The data gathered along the $\mathrm{x}=\mathrm{y}$ line; indeed, the RMA-derived regression slope was very close to 1 (slope $=0.99 \pm 0.16$ ) and the RMA-derived regression intercept was very close to 0 (intercept $=0.02 \pm 0.38$ ). And, though significant differences occasionally occurred between the two determinations, this is to be expected, due to the fact that the air mass measured by the in situ PTR-MS technique was considerably different from that measured by the remote sensing MAX-DOAS technique.

\section{Conclusions}

The detection sensitivity of $\mathrm{HCHO}$ and its humidity dependence by the PTR-MS were determined in laboratory experiments at three drift tube $E / N$ ratios: 108, 140, and $162 \mathrm{Td}$. We observed a discrepancy in detection sensitivities measured in dry conditions by two methods: (1) a direct introduction method, in which standard gas of $\mathrm{HCHO} / \mathrm{N}_{2}$ (1.02 ppmv) was analyzed directly, and (2) a dynamic dilution method, in which the $\mathrm{HCHO} / a$ ir mixture analyzed was produced by a dynamic dilution of the standard gas with zero air. The detection sensitivities obtained in the dynamic dilution method were approximately 2.7 times less than those obtained in the direct introduction method.

The detection sensitivity of PTR-MS for HCHO decreased with increasing humidity in all $E / N$ conditions. The detection sensitivities for $\mathrm{HCHO}$ were determined as a function of the water vapor concentration in the sample, $\left[\mathrm{H}_{2} \mathrm{O}\right]_{\text {sample }}$ ( $\mathrm{mmol} / \mathrm{mol})$ :

$$
\begin{aligned}
& S(\mathrm{ncps} / \mathrm{ppbv})=\frac{169}{\left[\mathrm{H}_{2} \mathrm{O}\right]_{\text {sample }}+13.1} \text { for } \mathrm{KE}_{\mathrm{cm}}=0.10 \mathrm{eV} \\
& S(\mathrm{ncps} / \mathrm{ppbv})=\frac{62.4}{\left[\mathrm{H}_{2} \mathrm{O}\right]_{\text {sample }}+9.5} \text { for } \mathrm{KE}_{\mathrm{cm}}=0.17 \mathrm{eV}
\end{aligned}
$$

$$
S(\mathrm{ncps} / \mathrm{ppbv})=\frac{30.9}{\left[\mathrm{H}_{2} \mathrm{O}\right]_{\text {sample }}+6.0} \text { for } \quad \mathrm{KE}_{\mathrm{cm}}=0.23 \mathrm{eV}
$$

In an intensive field campaign at Mount Tai in China in June 2006, most of the HCHO values determined by the calibrated PTR-MS method were higher than the corresponding MAX-DOAS values; this was partly caused by interference of fragment ions from methyl hydroperoxide, methanol, and ethanol. By subtracting the contribution of these fragment ions from the ion signals at $m / z 31$, the agreement between the PTR-MS data and the MAX-DOAS data was considerably improved.

Acknowledgements. The authors are grateful to participating members in the field campaign at Mount Tai in China, especially to K. Okuzawa (Hokkaido University) for his help with operation at Mount Tai. We are also grateful to S. Hatakeyama (Tokyo University of Agriculture and Technology) for providing the methyl hydroperoxide sample. S. Inomata is grateful to A. M. Ellis (University of Leicester) for comments in improving the manuscript. Funding support for this study was provided in part by the Global Environment Research Fund of the Ministry of the Environment, Japan (B-051), and Japan EOS Promotion Program (JEPP). Z. Wang acknowledges the support of National 973 Project (2005CB422205).

Edited by:J. Rinne

\section{References}

Ammann, C., Brunner, A., Spirig, C., and Neftel, A.: Technical note: Water vapor concentration and flux measurements with PTR-MS, Atmos. Chem. Phys., 6, 4643-4651, available at: http: //www.atmos-chem-phys.net/6/4643/2006/, 2006.

Aoki, N., Inomata, S., and Tanimoto, H.: Detection of $\mathrm{C}_{1}-\mathrm{C}_{5}$ alkyl nitrates by proton transfer reaction time-of-flight mass spectrometry, Int. J. Mass Spectrom., 263, 12-21, 2007.

Atkinson, R.: Atnospheric chemistry of VOCs and NOx, Atmos. Environ., 34, 2063-2101, 2000.

Ayers, G. P.: Comment on regression analysis of air quality data, Atmos. Environ., 35, 2423-2425, 2001.

Calvert, J. G., Atkinson, R., Kerr, S., Madronich, G. K., Moortgat, G., Wallington, T. J., and Yarwood, G.: The mechanisms of atmospheric oxidation of the alkenes, 371-379, Oxford Univ. Press, New York, 2000.

Cárdenas, L. M., Brassington, D. J., Allan, B. J., Coe, H., Alicke, B., Platt, U., Wilson, K. M., Plane, J. M. C., and Penkett, S. A.: Intercomparison of formaldehyde measurements in clean and polluted atmospheres, J. Atmos. Chem., 37, 53-80, 2000.

D’Anna, B. Wisthaler, A., Andreasen, Ø., Hansel, A., Hjorth, J., Jensen, N. R., Nielsen, C. J., Stenstrøm, Y., and Viidanoja, J.: Atmospheric chemistry of $\mathrm{C}_{3}-\mathrm{C}_{6}$ cycloalkanecarbaldehydes, J. Phys. Chem. A, 109, 5104-5118, 2005.

de Gouw, J. A., Goldan, P. D., Warneke, C., Kuster, W. C., Roberts, J. M., Marchewka, M., Bertman, S. B., Pszenny, A. A. P., and Keene, W. C.: Validation of proton transfer reactionmass spectrometry (PTR-MS) measurements of gas-phase organic compounds in the atmosphere during the New England Air 
Quality (NEAQS) in 2002, J. Geophys. Res., 108(D21), 4682, doi:10.1029/2003JD003863, 2003.

de Gouw, J. and Warneke, C.: Measurements of volatile organic compounds in the earth's atmosphere using proton-transferreaction mass spectrometry, Mass Spectrom. Rev., 26, 223-257, 2007.

Fried, A., Sewell, S., Henry, B., Wert, B. P., and Gilpin, T.: Tunable diode laser absorption spectrometer for ground-based measurements of formaldehyde, J. Geophys. Res., 102, 6253-6266, 1997.

Fried, A., Wang, Y., Cantrell, C., Wert, B., Walega, J., Ridley, B., Atlas, E., Shetter, R., Lefer, B., Coffey, M. T., Hannigan, J., Blake, D., Blake, N., Meinardi, S., Talbot, B., Dibb, J., Scheuer, E., Wingenter, O., Snow, J., Heikes, B., and Ehhalt, D.: Tunable diode laser measurements of formaldehyde during the TOPSE 2000 study: Distributions, trends, and model comparisons, J. Geophys. Res., 108(d4), 8365, doi:10.1029/2002JD002208, 2003.

Gao, J., Wang, T., Ding, A., and Liu, C.: Observational study of ozone and carbon monoxide at the summit of mount Tai (1534 m a.s.1.) in central-eastern China, Atmos. Environ., 39, 4779-4791, 2005.

Gilpin, T., Apel, E., Fried, A., Wert, B., Calvert, J., Genfa, Z., Dasgupta, P., Harder, J. W., Heikes, B., Hopkins, B., Westberg, H., Kleindienst, T., Lee, Y.-N., Zhou, X., Lonneman, W., and Sewell, S.: Intercomparison of six ambient $\left[\mathrm{CH}_{2} \mathrm{O}\right]$ measurement techniques, J. Geophys. Res., 102, 21 161-21 188, 1997.

Grabmer, W., Graus, M., Lindinger, C., Wisthaler, A., Rappenglück, B., Steinbrecher, R., and Hansel, A.: Disjunct eddy covariance measurements of monoterpene fluxes form a Norway spruce forest using PTR-MS, Int. J. Mass Spectrom., 239, 111115,2004

Grosjean, D.: Ambient levels of formaldehyde, acetaldehyde, and formic acid in Southern California: Results of a one-year baseline study, Environ. Sci. Technol., 25, 710-715, 1991.

Grossmann, D., Moortgat, G. K., Kibler, M., Schlomski, S., Bächmann, K. Alicke, B., Geyer, A.. Platt, U., Hammer, M.U., Vogel, B., Mihelcic, D., Hifzumahaus, A., Holland, F., and Volz-Thomas, A.: Hydrogen peroxide, organic peroxides, carbonyl compounds, and organic acids measured at Pabstthum during BERLIOZ, J. Geophys. Res., 108(D4), 8250, doi:10.1029/2001JD001096, 2003.

Hak, C., Pundt, I., Trick, S., Kern, C., Platt, U., Dommen, J., Ordóñez, C., Prévôt, A. S. H., Junkrtmann, W., Astrga-Lloréns, C., Larsen, B. R., Mellqvist, Strandberg, A., Yu, Y., Galle, B., Kleffmann, J., Lörzer, J. C., Braathen, G. O., and Vokamer, R.: Intercomparison of four different in-situ techniques for ambient formaldehyde measurements in urban air, Atmos. Chem. Phys., 5, 2881-2900, available at: http://www.atmos-chem-phys.net/5/ 2881/2005/, 2005.

Hansel, A., Singer, W., Wisthaler, A. Schwarzmann, M., and Lindinger, W.: Energy dependencies of the proton transfer reactions $\mathrm{H}_{3} \mathrm{O}^{+}+\mathrm{CH}_{2} \mathrm{O} \leftrightarrow \mathrm{CH}_{2} \mathrm{OH}^{+}+\mathrm{H}_{2} \mathrm{O}$, Int. J. Mass Spectrom., 167/168, 697-703, 1997.

Harris, G. W., Mackay, G. I., Iguchi, T., Mayne, L. K., and Schiff, H. I.: Measurements of formaldehyde in the troposphere by tunable diode laser absorption spectroscopy, J. Atmos. Chem., 8, 119-137, 1989.

Heckel, A., Richter, A. Tarsu, T., Wittrock, F., Hak, C., Pundt,
I., Junkermann, W., and Burrows, J. P.: MAX-DOAS measurements of formaldehyde in the Po-Valley, Atmos. Chem. Phys., 5, 909-918, available at: http://www.atmos-chem-phys.net/5/909/ 2005/, 2005.

Holzinger, R., Warneke, C., Hansel, A., Jordan, A., Lindinger, W., Scharffe, D. H., Schade, G., and Crutzen, P. J.: Biomass burnig as a source of formaldehyde, acetaldehyde, methanol, acetone, acetonitrile, and hydrogen cyanide, Geophys. Res. Lett., 26, 11611164, 1999.

Irie, H., Kanaya, Y., Akimoto, H., Iwabuchi, H., Shimizu, A., and Aoki, K.: Performance of MAX-DOAS measurements of aerosols at Tsukuba, Japan: a comparison with lidar and sky radiometer measurements, Atmos. Chem. Phys. Discuss., 7, 97699793, available at: http://www.atmos-chem-phys-discuss.net/7/ 9769/2007/, 2007.

Iwabuchi, H.: Efficient Monte Carlo methods for radiative transfer modeling, J. Atmos. Sci., 63, 9, 2324-2339, 2006.

Karl, T., Crutzen, P. J., Mandl, M., Staudinger, M., Guenther, A., Jordan, A., Fall, R., and Lindinger, W.: Variablity-lifetime relationship of VOCs observed at the Sonnblick Observatory 1999 - estimation of HO-densities, Atmos. Environ., 35, 5287-5300, 2001a.

Karl, T., Guenther, A., Jordan, A., Fall, R., and Lindinger, W.: Eddy covariance measurement of biogenic oxygenated VOC emissions from hay harvesting, Atmos. Environ., 35, 491-495, $2001 \mathrm{~b}$.

Karl, T., Hansel, A., Märk, T., Lindinger, W., and Hoffmann, D.: Trace gas monitoring at the Mauna Loa Baseline Observatory using Proton-Transfer Reaction Mass Spectrometry, Int. J. Mass Spectrom., 223, 527-538, 2003a.

Karl, T., Jobson, T., Kuster, W. C., Williams, E., Stutz, J., Shetter, R., Hall, S. R., Goldan, P., Fehsenfeld, F., and Lindinger, W.: Use of proton-transfer-reaction mass spectrometry to characterize volatile organic compound sources at the La Porte super site during the Texas Air Quality Study 2000, J. Geophys. Res., 108(D16), 4508, doi:10.1029/2002JD003333, 2003b.

Kurucz, R.L., Furenlid, I., Brault, J., and Testerman, L.: Solar flux atlas from 296 to 1300 nm, Natl. Sol. Obs., Sunspot, New Mexico, 1984.

Lawson, D. R., Biermann, H. W., Tuazon, E. C., Winer, A. M., Mackay, G. I., Schiff, H. I., Kok, G. L., Dasgupta, P. K., and Fung, K.: Formaldehyde measurement methods evaluation and ambient concentrations during the carbonaceous species methods comparison study, Aerosol Sci. Tech., 12, 64-76, 1990.

Lee, A., Goldstein, A. H., Keywood, M. D., Gao, S., Varutbangkul, V., Bahreini, R., Ng, N. L., Flagan, R. C., and Seinfeld, J. H.: Gas-phase products and secondary aerosol yields from the ozonolysis of ten different terpenes, J. Geophys. Res., 111, D07302, doi:10.1029/2005JD006437, 2006a.

Lee, A., Goldstein, A. H., Kroll, J. H., Ng, N. L., Varutbangkul, V., Flagan, R. C., and Seinfeld, J. H.: Gas-phase products and secondary aerosol yields from the photooxidation of 16 different terpenes, J. Geophys. Res., 111, D17305, doi:10.1029/2006JD007050, 2006b.

Lee, Y.-N. and Zhou, X.: Method for the determination of some soluble atmospheric carbonyl compounds, Environ. Sci. Technol., 27, 749-756, 1993.

Lindinger, W., Hansel, A., and Jordan, A.: On-line monitoring of volatile organic compounds at pptv levels by means of ProtonTransfer-Reaction Mass Spectrometry (PTR-MS): Medical ap- 
plications, food control and environmental research, Int. J. Mass Spectrom., 173, 191-241, 1998a.

Lindinger, W., Hansel, A., and Jordan, A.: Proton-trnsfer-reaction mass spectrometry (PTR-MS): on-line monitoring of volatile organic compounds at pptv levels, Chem. Soc. Rev., 27, 347-354, 1998b.

Meller, R., and Moortgat, G. K.: Temperature dependence of the absorption cross section of formaldehyde between 223 and 323 $\mathrm{K}$ in the wavelength range $225-375 \mathrm{~nm}$, J. Geophys. Res., 105, 7089-7101, 2000.

Paulsen, D., Dommen, J., Kalberer, M., Prévôt, A. S. H., Richter, R., Sax, M., Steinbacher, M., Weingartner, E., and Baltensperger, U.: Secondary organic aerosol formation by irradiation of 1,3,5trimethylbenzene- $\mathrm{NO}_{\mathrm{x}}-\mathrm{H}_{2} \mathrm{O}$ in a new reaction chamber for atmospheric chemistry and physics, Environ. Sci. Technol., 39, 2668-2678, 2005.

Rodgers, C. D.: Inverse methods for atmospheric sounding: Theory and practice, Ser. Atmos. Oceanic Planet. Phys., 2, edited by Taylor, F. W., World Sci., Hackensack, N.J., 2000.

Seinfeld, J. H. and Pandis, S. N.: Atmospheric Chemistry and Physics: From Air Pollution to Climate Change, John Wiley \& Sons, Inc., New York, 107-111, 1998.

Spanel, P. and Smith, D.: SIFT studies of the reactions of $\mathrm{H}_{3} \mathrm{O}^{+}$, $\mathrm{NO}^{+}$, and $\mathrm{O}_{2}^{+}$with a series of alcohols, Int. J. Mass Spectrom., 167/168, 375-388, 1997.

Spirig, C., Neftel, A., Ammann, C., Dommen, J., Grabmer, W., Thielmann, A., Schaub, A., Beauchamp, J., Wisthaler, A., and Hansel A.: Eddy covariance flux measurement of biogenic VOCs during ECHO 2003 using proton transfer reaction mass spectrometry, Atmos. Chem. Phys., 5, 465-481, available at: http: //www.atmos-chem-phys.net/5/465/2005/, 2005.
Steinbacher, M., Dommen, J., Ammann. C., Spirig, C., Neftel, A., and Prevot, A. S. H.: Perfomance characteristics of a protontransfer-reaction mass spectrometer (PTR-MS) derived from laboratory and field measurements, Int. J. Mass Spectrom., 239, 117-128, 2004.

Tanner, R. L. and Meng, Z.: Seasonal variation in ambient atmospheric levels of formaldehyde and acetaldehyde, Environ. Sci. Technol., 18, 723-726, 1984.

Vaghjiani, G. L. and Ravishankara, A. R.: Kinetics and mechanism of $\mathrm{OH}$ reaction with $\mathrm{CH}_{3} \mathrm{OOH}$, J. Phys. Chem., 92, 1948-1959, 1989.

Zavala, M., Herndon, S. C., Slott, R. S., Dunlea, E. J., Marr, L. C., Shorter, J. H., Zahniser, M., Knighton, W. B., Rogers, T. M., Kolb, C. E., Molina, L. T., and Molina, M. J.: Characterization of on-road vehicle emissions in the Mexico City Metropolitan Area using a mobile laboratory in chase and fleet average measurement methods during the MCMA-2003 field campaign, Atmos. Chem. Phys., 6, 5129-5142, available at: http://www.atmos-chem-phys.net/6/5129/2006/, 2006.

Zhou, X. and Mopper, K.: Apparent partition coefficients of 15 carbonyl compounds between air and seawater and between air and freshwater; Implications for air-sea exchange, Environ. Sci. Technol., 24, 1864-1869, 1990. 